\title{
Treatment of Bladder Stones in Children: Evaluation of the Different Treatment Modalities
}

\section{Çocuklarda Mesane Taşları: Farklı Tedavi Seçeneklerinin Değerlendirilmesi}

\author{
Doğuş GÜNEY'1, Tuğrul Hüseyin TiRYAKi²
}

${ }^{1}$ Health Sciences University, Ankara Child Health and Diseases Hematology Oncology SUAM, Department of Pediatric Surgery, Ankara, Turkey

${ }^{2}$ Health Sciences University, Ankara Child Health and Diseases Hematology Oncology SUAM, Department of Child Urology,

Ankara, Turkey

\begin{abstract}
Objective: The aim of this study was to retrospectively evaluate our experience on open cystolithotomy and intracorporeal cystolithotripsy in children with bladder stones.
\end{abstract}

Material and Methods: A total of 23 children with bladder stones were treated at our center between 2007 and 2016. Transurethral removal with basket catheter, transurethral cystolithotripsy / percutaneous cystolithotripsy with laser or open cystolithotomy approaches were preferred. The patients were evaluated according to the operation technique, stone burden, and complications, and compared with each other in terms of these criteria.

Results: Three girls and 20 boys, ranging in age from 1 to 16 years were evaluated. Stone sizes ranged from 5 to $50 \mathrm{~mm}$. We preferred transurethral cystolithotripsy in 7 patients, percutaneous cystolithotripsy in 4 patients, open cystolithotomy in 8 patients and transurethral removal with basket catheter in 4 patients. Twenty (87\%) patients had no complications. Complications occurred in three patient consisting of a mucosal laceration in one patient and lower urinary tract obstruction due to residual stones in the postoperative period in two patients. The average stone size was $22.6 \pm 12 \mathrm{~mm}$ in all patients who underwent open cystolithotomy and $16 \pm 9.04 \mathrm{~mm}$ in patients where the other methods were used.

Conclusion: We believe that open cystolithotomy is the most effective treatment method, especially for stones greater than $2 \mathrm{~cm}$.

Key Words: Bladder stone, Children, Cystolithotomy

\section{ÖZET}

Amaç: Çalıșmamızda mesane tașı olan çocuk hastalarda açık sistolitotomi ve intrakorporeal sistolitotripsi deneyimlerimizin sonuçlarını değerlendirmeyi amaçladık.

Gereç ve Yöntemler: 2007-2016 tarihleri arasında toplam 23 hasta kliniğimizde mesane taşı nedeni ile tedavi edildi. Tedavide sistoskopi ile basket kateterle taşın çıkarıması, lazer ile transüretral veya perkütan sistolitotripsi ve açık sistolitotomi yöntemleri tercih edildi. Hastalar tercih edilen operasyon tekniği, taș yükü ve operasyon sonrası görülen komplikasyonlar açısından birbirleri ile karşılaştıııldı.

Bulgular: Hastaların üçü kız, 20'si erkekti, yaşları 1 ila 16 yaş arasındaydı. Taş boyutlarının en küçük 5, en büyük 50 mm olduğu kaydedildi. Toplam 7 hastada transüretral sistolitotrpsi, 4 hastada perkütan sistolitotripsi ve 8 hastada açık sistolitotomi tercih edildi. Dört hastada tașlar ise basket kateter ile transüretral olarak çıkarıldı. Yirmi (\%87) hastada herhangi bir komplikasyon görülmedi. Komplikasyon görülen hastaların birisi taș çıkarlırken üretra mukozasında laserasyon gelişen hastaydı. Diğer iki hasta ise transüretral sistolitotripsi operasyonu sonrası rezidü fragmante taşlar nedeniyle alt üriner sistem obstrüksiyonu gelișen hastalardı. Açık sistolitotomi tercih edilen hastaların taș boyutu ortalamasının $22.6 \pm 12 \mathrm{~mm}$, diğer tekniklerin tercih edildiği hastaların taș boyutlarıın ortalamasının ise $16 \pm 9.04 \mathrm{~mm}$ olduğu görüldü.

Sonuç: Mesane taşı olan çocuk hastalarda taş boyutu $2 \mathrm{~cm}$ üzerinde ise açık sistolitotomi yöntemi tercih edilmesinin diğer yöntemlere göre daha efektif olduğunu düşünmekteyiz.

Anahtar Sözcükler: Mesane taşları, Çocuk, Sistolitotomi 


\section{OBJECTIVE}

The incidence of urolithiasis is increasing in childhood (1-3). Bladder stones constitute $30 \%$ of the urinary system stones in socioeconomically backward regions $(4,5)$. In an earlier report from Turkey on the years 1958 to 1960, bladder stones were seen in $42 \%$ of all pediatric urolithiasis cases (6). Malnutrition, particularly protein deficiency, was the main etiological factor. A subsequent report in 2009 showed bladder stones in only $2 \%$ of cases (7).

Although there is a gradual decrease in the incidence of bladder stones, our clinic still receives a relatively considerable number of children with bladder stones.

Developing endourological techniques offer different treatment options in bladder stones (8-13). There is very limited literature regarding the surgical or endourological treatment of bladder stones in children. We have evaluated retrospectively the cases of bladder stones treated within the last 10 years in our clinic. In this study, it was aimed to determine the most appropriate approach for treatment in cases with bladder stones.

\section{MATERIAL and METHODS}

We retrospectively reviewed the records of children who had undergone treatment of bladder stones at our institution from 2007 to 2016. Patients under 18 years of age, who had a bladder stone of greater than five millimeters, were included in the study. Patients who had bladder augmentation and/or spontaneously passed bladder stones were not included in the study.

Patient age, sex, stone size, additional urolithiasis, hydronephrosis, symptoms and symptom duration, surgical technique, complications, operation and hospitalization time, and metabolic analysis results of the removed stones were recorded. The stone burden was measured in millimeters.

Transurethral cystolithotripsy (TUCL), percutaneous cystolithotripsy (PCCL) and open cystolithotomy $(\mathrm{OC})$ were the preferred surgical techniques. Intravenous prophylactic antibiotics were given preoperatively in all patients. In patients with small stone size, the stone was removed by cystoscopy with a basket catheter without lithotripsy (Transurethral removal with basket catheter=TURBC). $8 \mathrm{Fr}$ or $9.5 \mathrm{Fr}$ cystoscopes were used for transurethral cystolithotripsy. The stone was broken with Holmium YAG laser in the transurethral or percutaneous cystolithotripsy methods.

In the percutaneous cystolithotripsy method, a 12-mm laparoscopy trocar was placed in the suprapubic region after creating bladder distension with saline with the guidance of the cystoscope light. All the patients were followed up with an urethral catheter after the operation.
Open cystolithotomy is performed with a suprapubic incision of about 15-20 mm after cystoscopic evaluation of the bladder and distention of the bladder with saline. The bladder stone is taken out from the incision with an 'over clamp' accompanied by the cystoscopy image.

All patients were assessed by operation technique, stone burden, and complications and then compared according to all these criteria. Comparison of numeric variables between the study groups was performed using the One-Way Anova test. A probability value ( $p$ value) $<0.05$ was considered statistically significant. All statistical calculations were performed using SPSS (Statistical Package for the Social Science; SPSS Inc., Chicago, IL, USA) version15 for Microsoft Windows.

\section{RESULTS}

Between 2007 and 2016, a total of 346 children underwent surgical intervention for urolithiasis at our clinic. Of those patients, 23 (6.64\%) had bladder stones. The 3 girls (13\%) and 20 boys (87\%), for a total of 23 children ranging from 1 to 16 years of age (mean age $65.7 \pm 48.1$ months) were evaluated retrospectively.

The most common presenting symptom was urinary tract infection, which occurred in seven patients (30.5\%). Other common symptoms were dysuria $(n=7)$, hematuria $(n=3)$, incontinence $(n=3)$, and abdominal pain $(n=3)$.

We found additional abnormalities in ten (43.5\%) in our cases. These anomalies included cystinuria in two patients, and thalassemia major, meningocele, SSPS, anal atresia, vesicoureteral reflux, undescended testis, distal hypospadias and gluten enteropathy in one patient each (Table I).

Stone sizes ranged from 5 to $50 \mathrm{~mm}$ (mean $19.43 \pm 10.9 \mathrm{~mm}$, median $17 \mathrm{~mm}$ ). In two patients, bladder neck located stones were moved into the bladder with the cystoscope and than removed by cystoscopy with a basket catheter. In seven (30.4 $\%)$ cases, renal stones accompanied bladder stones.

Duration of the symptoms varied between two days to two years (mean $127+177,3$ days). Urinary ultrasound was normal in $14(61 \%)$ patients while there was bladder wall thickening or trabeculation in 9 (39\%) patients. Of the patients, 19 (82.6\%) had no or mild hydronephrosis, whereas $4(17.4 \%)$ had moderate or severe hydronephrosis.

For removal of bladder stones, we preferred TUCL in 7 (30.4\%) patients, PCCL in 4 (17.4\%) patients, OC in 8 (34.8\%) patients and TURBC in 4 (17.4\%) patients. Twenty (87\%) patients had no complications and were discharged with full recovery without any residual bladder stone. Superficial mucosal laceration occurred in the urethra during transurethral removal with a basket catheter in one of the three patients that developed complications. In 
Table I: Demographic characteristics of patients and accompanying diseases.

\begin{tabular}{ll}
\hline Age & $\mathbf{1 - 1 6}$ years (mean $\mathbf{6 5} \mathbf{+ 4 8 . 1}$ months) \\
\hline Female/Male & $3 / 20$ \\
& Difficulty in micturition $(n=7)$ \\
Clinical presentations & Urinary tract infection $(n=7)$ \\
& Incontinence $(n=3)$ \\
& Abdominal pain $(n=3)$ \\
& Hematuria $(n=3)$ \\
& Cystinuria $(n=2)$ \\
& Neurogenic bladder (meningomyelocele, SSPE, anal atresia) $(n=3)$ \\
& Vesicoureteral reflux $(\operatorname{VUR})(n=1)$ \\
Accompanying diseases & Distal hypospadias $(n=1)$ \\
& Unilateral undescended testis $(n=1)$ \\
& Thalassemia minor $(n=1)$ \\
& Celiac disease $(n=1)$ \\
& None $(n=13)$ \\
\hline
\end{tabular}

Table II: Complications.

\begin{tabular}{l|ll}
\hline & \multicolumn{2}{c}{ Patients } \\
& $\mathbf{n}$ & $\%$ \\
\hline Postoperative bladder outlet obstruction & 2 & 8.7 \\
Mucosal laceration of the urethra & 1 & 4.35 \\
\hline
\end{tabular}

Table III: Results of stone analysis.

\begin{tabular}{l|r|r}
\hline & $\mathbf{n}$ & $\%$ \\
\hline Whewellite & 10 & 43.1 \\
\hline Weddellite & 1 & 4.4 \\
Cystine & 2 & 8.8 \\
Struvite & 3 & 13.0 \\
\hline Mix & 5 & 21.7 \\
\hline
\end{tabular}

the other two patients, holmium:YAG laser-induced TUCL was conducted and lower urinary tract obstruction developed due to residual stones in the post-operative period (Table II). These patients were re-operated by the open method after achieving no benefit from irrigation or medical treatment. Four patients' operations were converted to an open procedure because of failed endoscopic methods (2 of them were TUCL, 2 of them were PCCL). The cause of failure was the excess amount of stone burden.

The results of stone analysis were recorded for 21 patients. In the remaining two patients, samples could not be sent for analysis because all the stones were fragmented. The result of the analyses are shown in Table III.

The rate of complications were $28.5 \%$ in patients who underwent TUCL and 25\% in patients who underwent TURBC. No complications were seen in patients who underwent $\mathrm{OC}$ and PCCL. There was no statistically significant difference by the number of complications between the OC and PCCL patient groups. The duration of surgery was significantly longer in patients who additionally underwent rectourethral fistula repair, dilatation of urethral stricture, and double j catheter placement due to nephrolithiasis during the removal of the bladder stone.

The hospitalization time was significantly shorter in patients who underwent TURBC (mean=3.5 days) when compared with the other operation techniques $(\mathrm{OC}=8$ days, $T U C L=7.5$ days, $P C C L=4$ days $)(p=0.001)$. The average stone size was $24.2+12.14 \mathrm{~mm}, 20.25+12.9 \mathrm{~mm}, 19.25+1.5 \mathrm{~mm}$ and 9.5+3.1 in patients who underwent TUCL, OC, PCCL and TURBC respectively. The average stone size was significantly different between the TUCL, OC, PCCL and TURBC groups. ( $p=0.038)$ (Table IV). In addition, the average stone size was $22.6+12$ $\mathrm{mm}$ in patients who underwent open cystolithotomy (primarysecondary) and 16+9.04 $\mathrm{mm}$ in patients who underwent other operation methods. The difference between these two average values was statistically significant $(p=0.001)$.

\section{DISCUSSION}

Bladder stones are endemic in developing regions such as Southeast Asia and India (4,5,14-16). However, upper urinary tract stones are common in developed countries $(17,18)$. The localizations of urinary stones have been observed to be displaced from the bladder to the upper urinary tract (19). In our study, patients with bladder stones accounted for $6.64 \%$ of 
Table IV: Comparison of the techniques in terms of hospitalization duration and stone size.

\begin{tabular}{l|c|c|c|c|c}
\hline & TUCL $(\mathbf{n}=\mathbf{7})$ & OC $(\mathbf{n}=\mathbf{8})$ & PCCL $(\mathbf{n}=\mathbf{4})$ & TURBC $(\mathbf{n}=\mathbf{4})$ & $\mathbf{p}$ \\
\hline Hospitalization duration (days) & 7.5 & 7.27 & 4 & 3.5 & 0.001 \\
\hline Stone size $(\mathbf{m m})$ & $24.2 \pm 12.14$ & $19.25 \pm 1.5$ & $20.25 \pm 12.9$ & $9.5 \pm 3.1$ & 0.038 \\
\hline
\end{tabular}

all patients who underwent surgical intervention due to urinary tract stones.

The presence of upper urinary tract calculi is not necessarily a predisposition to the formation of bladder stones. In our study, concurrent urolithiasis was found in $30.4 \%$ of the patients. Our study is also consistent with literature in terms of the higher incidence of bladder stone in boys $(\mathrm{m} / \mathrm{f}=6.6 / 1)$.

The mean age of the patients in our series was $5.4 \pm 4$ years and the rate of patients under the age of five was $60 \%$. The most common presenting symptoms were dysuria (30.4\%) and complaints related to UTIs (30.4\%).

The treatment options available for bladder stones in children include extracorporeal shockwave lithotripsy, transurethral cystolithotripsy, open cystolithotomy and percutaneous suprapubic cystolithotripsy. The treatment of pediatric bladder stones has changed radically with the development of endoscopic equipment and the widespread application of the YAG laser (2-5). The traditional method of treatment for patients with the bladder stone is cystolithotomy and this is a viable option in cases of large, hard vesical calculi $(9,10)$.

Extracorporeal shockwave lithotripsy treatment is a technically easy method to treat bladder stones, but its application may be questionable in children because of the difficulty in passing the stone fragments $(15,20)$.

We performed successful transurethral removal with a basket catheter for stones smaller than $1 \mathrm{~cm}(5$ to $11 \mathrm{~mm}$, mean 3.5 $\mathrm{mm})$. There were no major complications in this patient group and the duration of hospitalization with this technique was significantly shorter than that of the other techniques. The size of the stone is a key factor in cystoscopic removal of stones with a basket catheter without lithotripsy.

Transurethral cystolithotripsy is an alternative, although not ideal in the pediatric population. In children, a smaller-caliber urethra limits effective treatment of large bladder stone burdens. The long operating time and the removal of the fragments can easily cause urethral injury if the transurethral route is chosen. In addition, it can be difficult to fragment the mobile stones in the bladder by TUCL. Moreover, residual stones can be trapped in the urethra and cause excessive pain. It should be noted that the rate of complications in the present study was highest in TUCL technique (28.6\%), albeit statistically insignificant. In addition, the duration of hospitalization in this group was longer than other techniques (mean of $7.5 \pm 6.8$ days). In the literature, successful results have been achieved with TUCL in cases where the stone size was less than $2 \mathrm{~cm}$ (13). In our study, no complications were encountered during or after the TUCL procedure in cases with stone sizes between 1 and $2 \mathrm{~cm}$ (mean, $14.3 \mathrm{~mm}$ ).

Percutaneous suprapubic lithotripsy has recently become an alternative treatment option for bladder stones in children. In our study, PCCL was performed in 4 patients and in two of these patients it was necessary to convert the technique to open surgery because of an excessive stone burden. PCCL has many advantages, especially in pediatric patients, such as decreased urethral injury, no need for postoperative catheter insertion in most cases, and shorter operative time. However the surgery and anesthesia would have taken a long time for stones bigger than $1 \mathrm{~cm}$ and the clearance of the stone is not completed properly in some cases. The reported complications of percutaneous suprapubic lithotripsy in the literature include paralytic ileus, abdominal distension, intraperitoneal bladder perforation, and persistent urinary leakage from the treated suprapubic site by prolongation of catheterization $(11,13)$. PCCL management offers a shorter hospital stay but the complication rate is higher than $\mathrm{OC}$ (13).

Open surgery was considered the gold standard treatment of bladder lithiasis in pediatric patients for a long time, offering excellent success rates (6). In our study, most patients (73.6\%) had a stone greater than $1 \mathrm{~cm}$ and $\mathrm{OC}$ was preferred primarily or secondarily due to failure of endoscopic techniques. None of our patients who underwent open surgery (primarily or secondarily) had complications. Open cystolithotomy is performed through a 20-mm incision. Unlike techniques using a percutaneous trocar, it is possible to remove even large stones easily and completely with open cystolithotomy because of expandability of the incision.

The small number of patients, and the retrospective nature were the limitations of our study. A prospective study would be the ideal method to better identify indications of surgical treatment and all factors associated with failure and complications in children with a bladder stone.

\section{CONCLUSION}

The best treatment modality choice depends on the stone size and number. Complete stone clearance is difficult in patients with a big stone after cystolithotripsy (percutaneous/ transurethral) because of the wide space of the bladder. Open surgery was $100 \%$ effective in the removal of bladder stones. We believe that the removal of bladder stones can be safely 
performed by transurethral removal with a basket catheter in patients with bladder stones smaller than $1 \mathrm{~cm}$ in size. The most effective treatment method is OC for patients with stones greater than $1 \mathrm{~cm}$, in particular greater than $2 \mathrm{~cm}$.

\section{REFERENCES}

1. Edvardsson V, Elidottir $\mathrm{H}$, Indridason OS, Palsson R. High incidence of kidney stones in Icelandic children. Pediatr Nephrol 2005;20:940-4

2. Van Dervoort K, Wiesen J, Frank R, Vento S, Crosby V, Chandra $\mathrm{M}$, et al. Urolithiasis in pediatric patients: A single center study of incidence, clinical presentation and outcome. J Urol 2007;177:2300-5.

3. Lopez M, Hoppe B. History, epidemiology and regional diversities of urolithiasis. Pediatr Nephrol 2010;25:49-59.

4. Bichler $\mathrm{KH}$, Strohmaier WL, Korn S. Urolithiasis in childhood. Monatsschr Kinderheild 1985;133:256-66.

5. Johnson O. Vesical calculus in Ethiopian children. Ethiop Med $J$ 1995;33:31-5.

6. Eckstein HB. Endemic urinary lithiasis in Turkish children: A clinical study of 119 cases. Arch Dis Child 1961;36:137-45.

7. Alpay H, Ozen A, Gokce I, Biykli N. Clinical and metabolic features of urolithiasis and microlithiasis in children. Pediatr Nephrol 2009;24:2203-9.

8. Sofer M, Kaver I, Greenstein A, Yosef YB, Mabjeesh NJ, Chen J, et al. Refinements in treatment of large bladder calculi: Simultaneous percutaneous suprapubic and transurethral cystolithotripsy. Urology 2004;64:651-4.

9. Phillippou P, Moraltis K, Masood J, Junald I, Buchholz N. The management bladder lithiasis in the modern era of endourology. Urology 2012;79:980-6.
10. Dhaballa JV, Jaln N, Kumar V, Nelivigi GG. Modified technique of percutaneous cystolithotripsy using a new instrument combined single step trocar dilator with self retaining adjustable access sheath. Urology 2011;77:1304-7.

11. Salah MA, Holman E, Khan AM, Toth C. Percutaneous cystolithotomy for pediatric endemic bladder stone: Experience with 155 cases from 2 developing countries. J Pediatr Surg 2005;40:1628-31.

12. Aboulela W, El Sheemy MS, Shoukry AI, Shouman AM, El Shenoufy A, Daw K, et al. Transurethral holmium laser cystolithotripsy in children: Single center experience. J Endourology 2015;29:661-5.

13. Al-Marhoon MS, Sarhan OM, Awad BA, Helmy T, Ghali A, Dawaba MS. Comparison of endourological and open cystolithotomy in the management of bladder stones in children. J Urol 2009;181:26848.

14. Naqvi SAA, Rizvi SAH, Shahjehan S. Analysis of urinary calculi by chemical methods. J Pak Med Assoc 1984;34:147-53.

15. Rizvi SAH, Sultan S, Zafar MN, Ahmed B, Faiq SM, Hossain $\mathrm{KZ}$, et al. Evaluation of children with urolithiasis. Indian $\mathrm{J}$ Urol 2007;23:420-7.

16. Bakane BC, Nagtilak SB, Patil B. Urolithiasis: A tribal scenario. Indian J Pediatr 1999;66:863-5.

17. Ece A, Ozdemir E, Gurkan F, Dokucu Al, Akdeniz O. Characteristics of pediatric urolithiasis in South-East Anatolia. Int J Urol 2000;7:3304.

18. Schwartz BF, Stoller ML. The vesical calculus. Urol Clin North Am 2000;27:333-46.

19. Ozokutan BH, Kucukaydin M, Gunduz Z, Kabaklioglu M, Okur H, Turan C. Urolithiasis in childhood. Pediatr Surg Int 2000;16:60-3.

20. Khosa AS, Hussain M, Hussain M. Safety and efficacy of transurethral pneumatic lithotripsy for bladder calculi in children. J Park Med Assoc 2012;62:1297-300. 